triplo superantibus.

Nom. Jap. Hosizaki-inunohige (nov.).

Hab.

Honsyû:: Prov. Settu, in oppido Toyonaka-mati (N. Ur, no. 22, Sept. 23, 1934-typus).

Kyûsyû: Prov. Higo, Menda (K. Mayebara, no. 355, Oct. 17, 1929).

Distr. Endemica.

\title{
Development and Structure of a New Species of Octaviania (Hymenogastraceae).
}

By

\section{Yosio Kobayasi.}

With 1 Plate and 8 Text-figures.

Received March $29,1937$.

\section{Historical Sketch of the Systematic Treatment of the Genus.}

The genus Octaviania VitTadini was proposed by its author, VitTadini, in 1831, certain members of which are now included in Melanogaster of the Melanogastraceae. In 1842, ZoBEL combined the genus Hydnangium Wallroth (1839) with Octaviania, and later, Tulasne (1851), although following ZовеL in the main, excluded the members of Melanogaster, and recognized the said genus. This treatment was followed by C. G. Lloyd, W. C. Coker, J. N. Couch and others, but at present, the genus Hydnangium, the development of which was studied by L. Petri (1902), is acknowledged by many mycologists to be a distinct one in the Hydnangiaceae. On the other hand, the development of Octaviania is entirely unknown, so that the definition of the genus is imperfect, especially of its relation to the genera in the same family Hymenogastraceae. Since 1919, S. M. Zeller and C. W. Dodge, in the course of their studies of Hydnangiaceae, distributed the members of Octaviania among the genera Hydnangium, Arcangeliella, Sclerogaster and Elasmomyces, all of which are related to one another. They are of the opinion that the name Octaviania was originally used as a synonym of Melanogaster, and in 1935 the type species 
Octaviania asterosperma VIтT. was also transferred to Arcangeliella along with almost all the members of Octaviania, although proof seems lacking that $O$. asterosperma is a developmental type of Arcangeliella, at any rate in the generic definition sustained by E. Fischer (1933). The fungi belonging to the genus Octaviania Vitr. emend. E. Fiscuen, which were collected and studied by the writer, were found as a result of the following observations to be another developmental type from the genera of Hydnangiaceae. The writer, in this paper, expects to enumerate the distinct characteristics of Octaviania.

\section{Materials and Methods.}

Since 1930, the writer had noticed the occurrence of a hitherto unrecorded species of Octaviania every October in the Koisikawa Botanical Garden of the Tokyo Imperial University, and in 1933 fixed the young fruitbodies of this species. In addition to these, much materials from a number of localities near Tokyo were used for study. For fixing, AlLEN's modification of Boun's solution was tried and the material embedded in paraffin. Serial sections were cut $10 \mu$ thick and stained in DeLafield's haematoxylin.

\section{Observations.}

The fruitbody arises from the indistinct rhizomorph, which is whitish, thin, much branched, and undifferentiated into cortex and central core. When the fruitbody is very young it is subhypogenous and usually elongated, about $2.5-3 \mathrm{~mm}$. in diameter, with obconical base, after which it emerges from the ground, becoming tuberiform or globose.
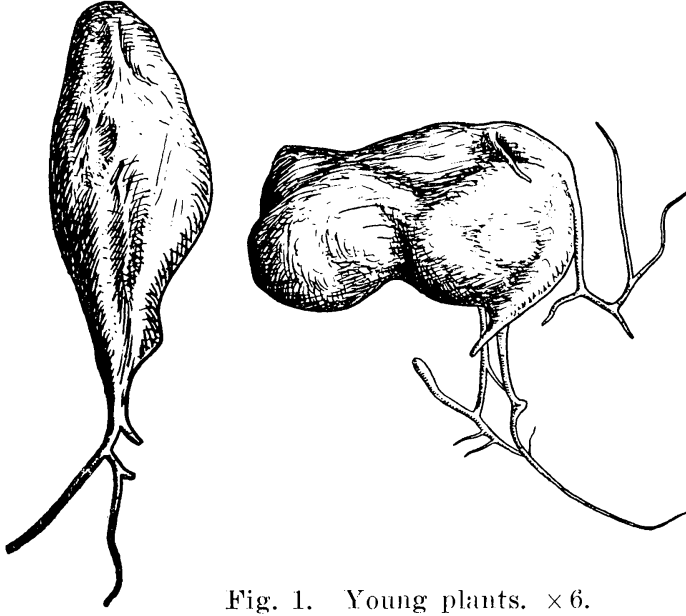

Fig. 1. Young plants. $\times 6$.
The fungus illustrated in Text-fig. 1. (left) has the interior undifferentiated (Pl. VI, Fig. A) with no formation of peridium. Its inner tissue (Pl. VI, Fig. E) is made up of densely interwoven hyphae which are about $4-9 \mu$ in diameter. The outer fringe of the plant stains more deeply than the inner part. At a slightly advanced stage, differentiation of the tissue occurs in its apical part, where the 


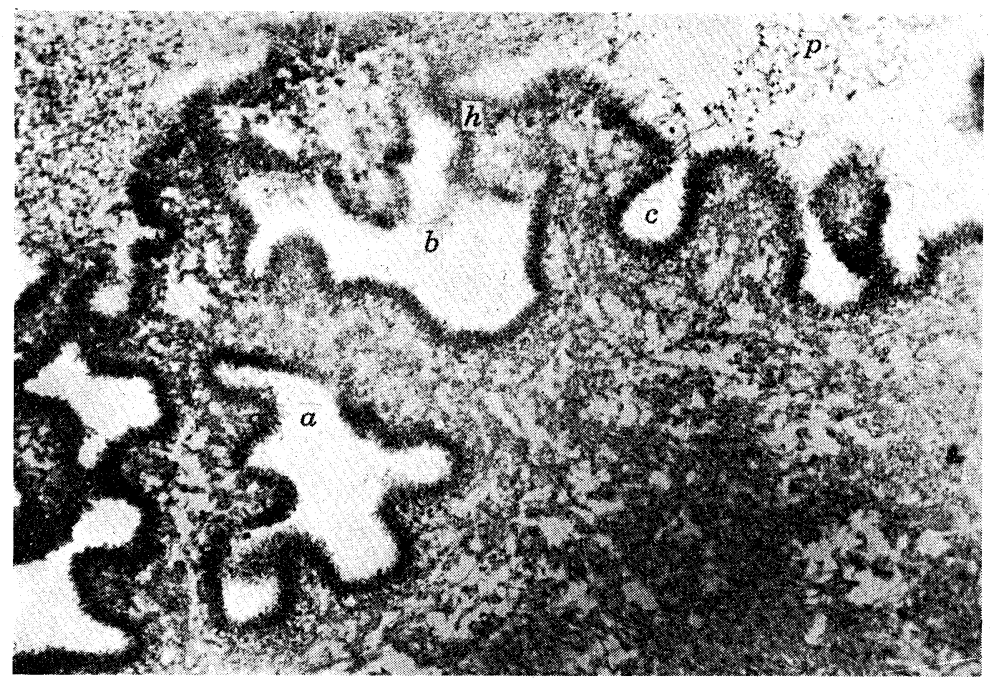

Fig. 2. Section of periphery of young gleba, showing formation of chambers. $a$, closed chamber; $c$, open chamber; $b$, transitional stage; $h$, point where hymenial fundaments growing from opposite sides fuse together; $p$, primary peridium. $\times 75$.

pseudoparenchymatous hyphae are arranged somewhat densely, forming a palisade layer (Pl. VI, Fig. B and D, $h$ ) that runs parallel to the surface of the fruitbody, in which manner the growth of the hymenial fundament begins. Through intercalary growth of the inner tissue $(i)$, the hymenial fundament is pushed out in places toward the surface, forming several arches $(a)$ and the folds $(f)$ between them.

The peripheral part outside this layer, which becomes the primary peridium $(p)$, is composed of loosely woven hyphae that arrange themselves parallel to the surface of the fruitbody. Each hypha becomes somewhat thicker and denser coloured than that of the inner tissue, although in other respects there is no distinct difference between these two tissues. The tips of the arches spread out under the primary peridium, forming the tramal plates (Pl. VI, Fig. C, $t$ ), which fuse closely with the peridium, seeming sometimes to form themselves in isolated tramal peridium. The folds of the hymenial fundament elongate and gradually penetrate the inner tissue, with the result that the latter forms multi. folded outline. Later the inner tissue becomes the columella with radially arranged branches. As illustrated in Text-fig. 2, each fold fringed by the hymenial fundamental becomes labyrinthiform by gradual foldings, and forms chambers by closure of the folds $(h)$. The chambers that are formed near the surface of the fruitbody remain opened outwards $(c)$. The chambers, thus formed, continue to elongate through successive increase in the number of the bordering palisade cells. By fusion of the opposite 
palisade cells at the narrow necks of the chamber new cavities are successively formed. Each group of chambers formed from one fold (Text-figs. 3 and 4) are separated by the radially arranged branches of the columella. Following the formation of the chambers, the formation of a definite hymenium begins instead of the hymenial fundament, be-

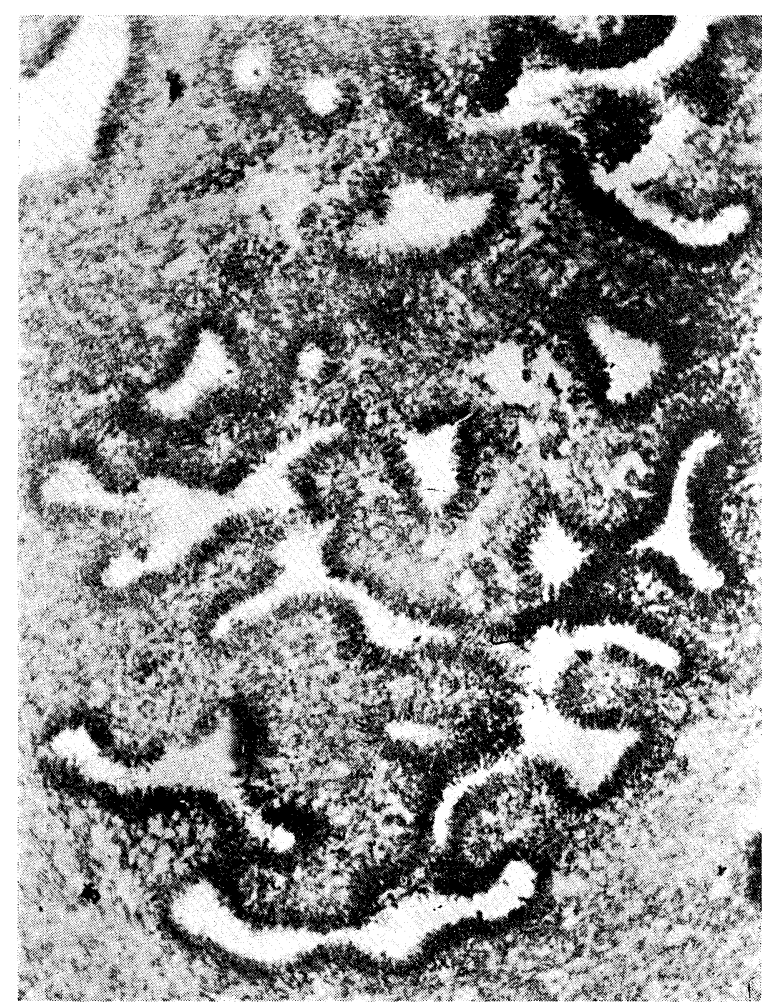

Fig. 3. A group of glebal chambers formed from one fold. $\times 75$. coming richer in its protoplasma. As soon as the fruitbody becomes fairly large, the colour of the spores turns dark, the free spores sometimes filling the inner chambers (Pl. VI, Fig. G). The tramal tissue of the gleba is almost hyaline. The columella is almost fleshy in its texture during the whole course of the differentiation of all the other parts. Frequently a cavity is formed in its inner part (Text-figs. 4 and 6 ) and, after maturity, the columella becomes more or less gelatinous, then collapses with the other parts of the fruitbody. When the pale coloured columella is exposed to air by cutting through it, or the ochraceous surface of the peridium is rubbed, they immediately turn purplish blue or grayish and finally dark.

\section{Conclusion.}

Judging from the developmental type of this organism, the writer would place this fungus in the group of "Koralloider Typus", although it has a few characteristics belonging to "Mehrhütiger Typus", both LoHw.AG's types. On the otehr hand, the members of Hydnangium and Arcangeliella of Hydnangiaceae are regarded as of the "Einhütiger Typus", with the species of which the above mentioned fungus does not seem to be congeneric. There are many differentiating characters between 


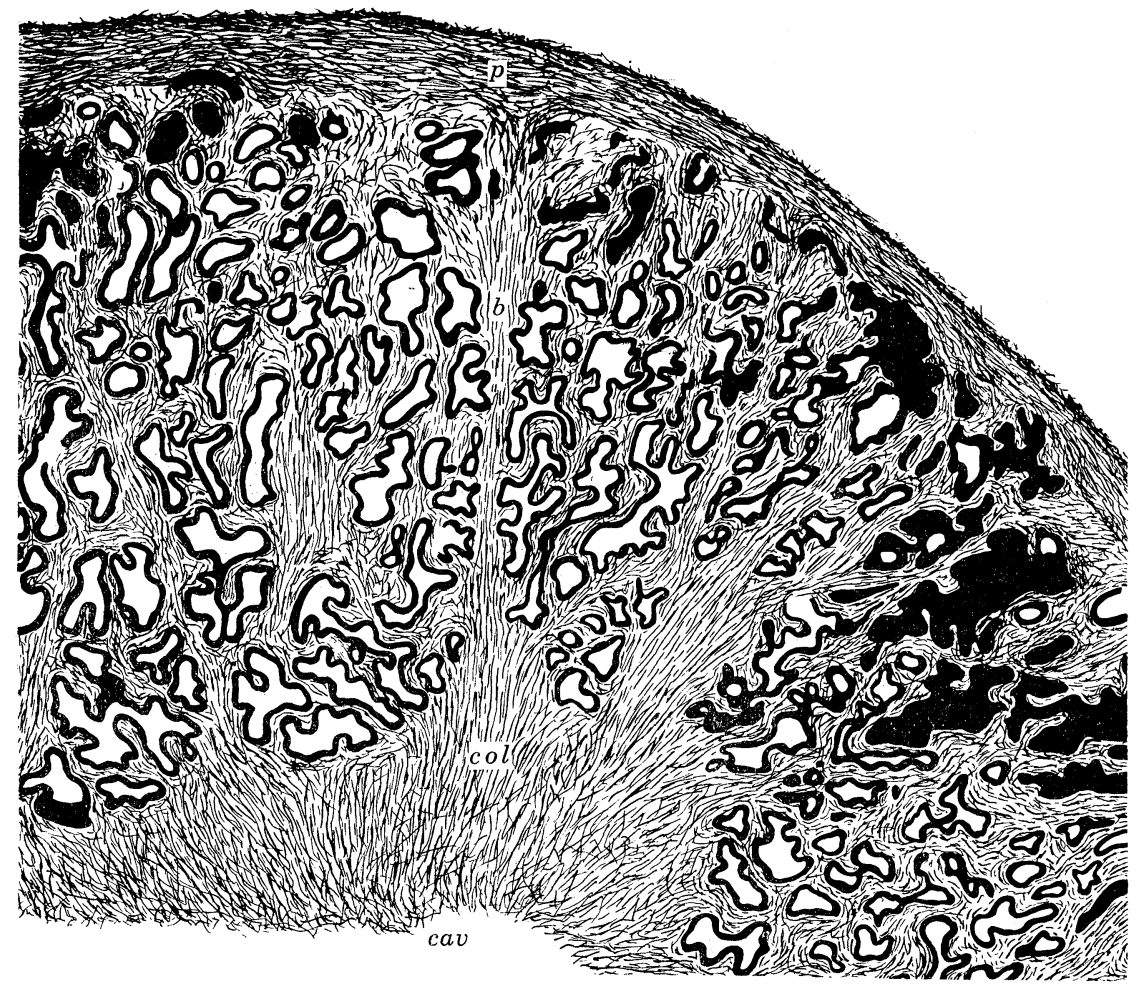

Fig. 4. Section of fruitbody in advanced stage, showing primary peridium $(p)$, glebal chambers, branches (b), and cavity (cav) of columella (col). $\times 12$.

the genera Octaviania and Hydnangium (including Arcangeliella), such as the presence of columella or sterile base, splitting of tramal plates, colour of spores, separability and consistency of the peridium. Over and above all these characters, it is the developmental type that should be taken as fundamental, should the type species Octaviania asterosperma be found to be another type removed from that of Hydnangium, as regarded by LoHwag, who writes "bei Octaviania asterosperma möchte ich glauben, dass ein koralloider Fruchtkörper vorliegt mit etwas flachen Ästen, durch deren Anastomosieren ringsum geschlossene Kammern zustande kommen'.

From the morphological point of view, the writer temporarily places this fungus in Octaviania, confident that even were the genus to be placed in Hydnangium as the result of studies, the writer's organism will at any rate remain to create a new genus. The genus Octaviania has some affinity with Martellia, Dendrogaster and Sclerogaster, all of the genus of the Hymenogastraceae, while it also resembles Maccagnia and Hoehneliogaster of the Hysterangiaceae. 


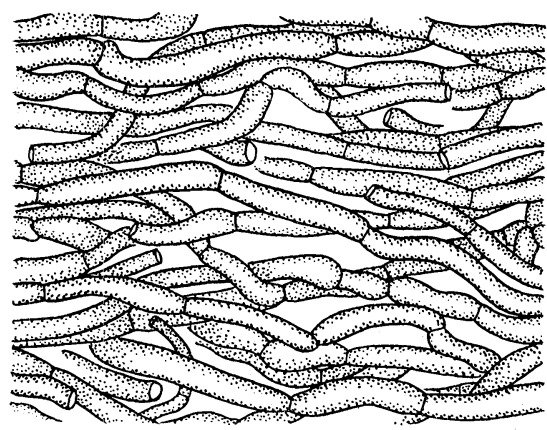

Fig. 5. Section of peridium. $\times 375$.
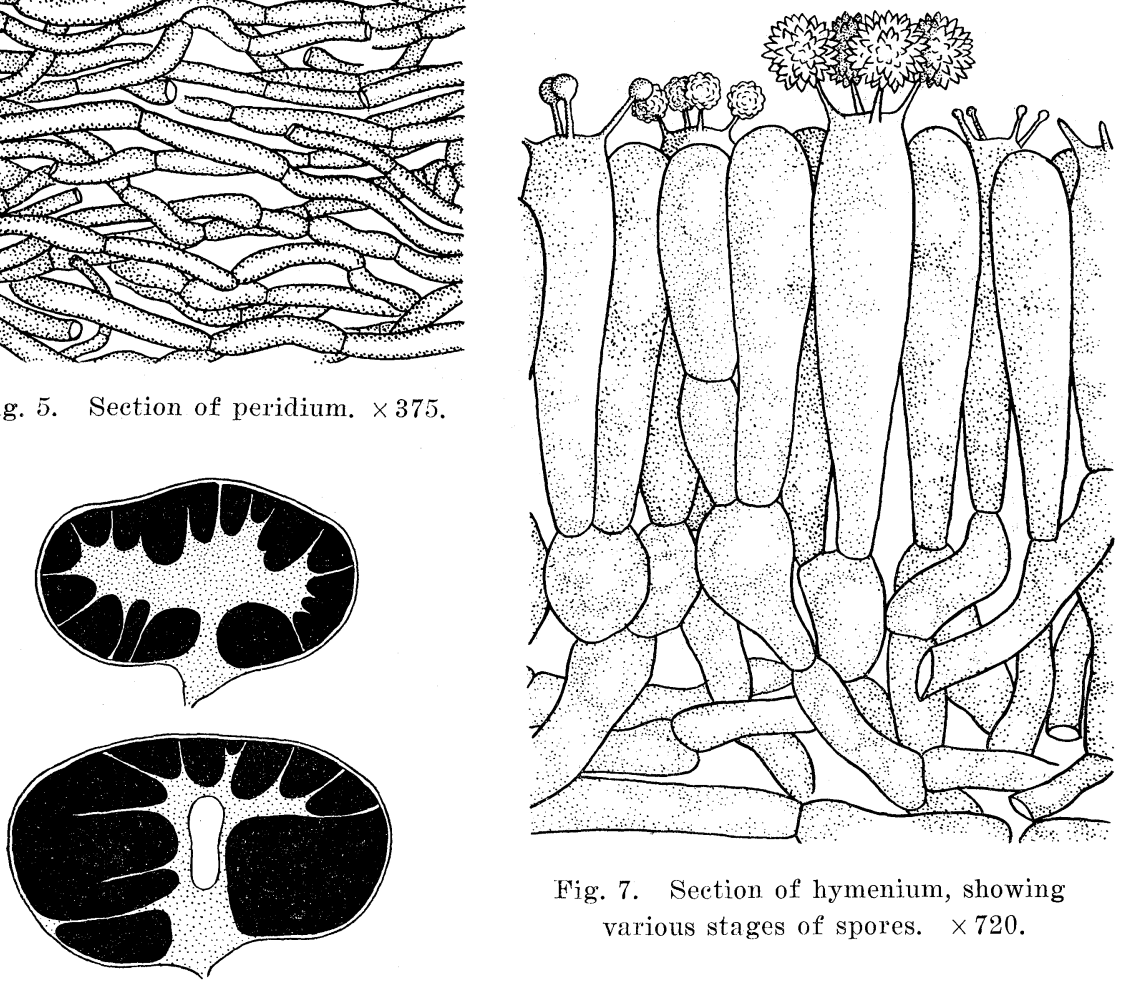

Fig. 7. Section of hymenium, showing various stages of spores. $\times 720$.

Fig. 6. Median section of fruitbody. $\times 2 / 3$.
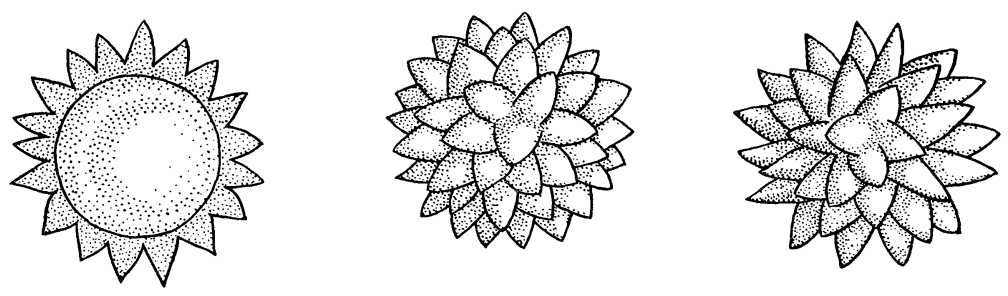

Fig. 8. Mature spores. $\times 1500$.

\section{Description of the Fungus.}

Octaviania (Hymenogastraceae).

Vitrtadini, Monographia Tuberacearum, p. 15 (1831) emend. Tulasne, Fungi Hypogaei, p. 77 (1851) et Fischer, in EngL. Pflanzenfam. VIIa, p. 17 (1933).

Type Species: O. asterosperma VITT. 1. c. 
Octaviania columellifera Y. KobAYASI sp. nov.

Fungus in juventute pyriformis vel ovoideus, per aetatem subglobosus aut tuberiformis, 4-7 $\mathrm{cm}$. diam. basi tuberculatus, radice albis brevi ramosa instructus; superficie glabra, primum lutescente, dein ochracea (ChamoisDeep Colonial Buff), tactu nigrescente, demum rimosa. Peridium simplex, a gleba non separabile, difficile penetrabile per aquam, 0.15-1 mm. crassum, arachnoideo-fibrillosum; hyphis septatis, hyalinis $5-8 \mu$ crassis, plus minusve parallele ordinatis. Columella crassa e fungi basi oriunda (uti in Hysterangio), radiate ramosa, ramis saepe ad peridium extentis, lentocarnosa, deinde subgelatinosa, e hyphis septatis $4-6.5 \mu$ diam. hyalinis composita, fracta sectave caerulescens, intus saepissime irregulariter excavata. Gleba carnoso-elastica, primo albida, tandem pallido-ochracea, denique fuscescens, per ramos columellae in partibus obconicis partita; locellis numerosis, subovoideis vel irregulariter elongatis. Trama $0.1-0.2 \mathrm{~mm}$. crassa, e hyphis septatis hyalinis $4-5 \mu$ diam. ramosis composita, sine capillitio. Iymenium e paraphysibus et basidiis densissime implexis, quae hyphis externis tramae ortis, constitutum; cystidiis nullis. Basidia clavata 45-60×10-14 , pallido-ochracea, tetraspora; sterigmatibus longiusculis laxe elongatis. Sporae globosae, dense spinis magnis pyramidatis ornatae, 15$20 \mu$ diam. (cum spinis) fere $16 \mu$ diam. ex ochraceis olivaceo-fuscescentes (Deep Olive Buff), uniguttulatae, non pedicellatae. Sparsa vel subgregaria, subhypogena superficialisque. Odor foetidus.

Chemical reactions of the young gleba:

With guaiac or ethyl alcohol, + pale reddish yellow (Flesh Ochre) $\rightarrow$ dark blue.

With acid $\left(\mathrm{HCl}, \mathrm{HNO}_{3}, \mathrm{H}_{2} \mathrm{SO}_{4}\right)$, - .

With alkali $(\mathrm{NaOH}),-\quad$ pale yellowish.

With iodine or formalin, + reddish $\rightarrow$ dark purple.

Nom. Jap. Zyagaimo-take (nov.)

Hab. Growing among mosses or fallen leaves. Japan.

Koisikawa Bot. Gard. Imp. Univ. Tokyo (Y. Kobayasi, Oct. 14, 1930); Mt. Takao, prov. Musasi (Sept. 1932); Kunitati, prov. Musasi (Oct. 1936); Kônodai, prov. Simôsa (Oct. 1933).

This species may be distinguished from $O$. asterosperma VITT. (Arcangeliella asterosperma Z. et D.) and O. mutabilis (non Hesse) Roum. by the following characters.

The species also resembles O.borneensis PETRI (Elasmomyces borneensis Z. et D.) and O. Ravenelii (BERK.). LLoRD (Hydnangium Ravenelii CuRTIS), both of which have the columella, but differ in their spores. 


\section{O. asterosperma.}

Fructification regularly globose, with sterile base, but lacking columella; chambers of gleba spherical or ovoid, small in periphery and larger in middle of gleba; tramal plate splitting later.

\section{O. mutabilis.}

Peridium separates; with fugacious tomentum; spores $12-15 \mu$.

\section{o. columellifera.}

Fructification tuberiform, irregular, with distinct columella, the ehambers of which are radially arranged and reach the peridium; chambers of gleba labyrinthiform or ovoid; tramal plate not splitting later.

Peridium does not separate; without tomentum; spores $15-20 \mu$.

$$
\begin{gathered}
\text { Botanical Institute, Tokyo Bumrika Daigaku, } \\
\text { Tokyo. }
\end{gathered}
$$

\section{Literature.}

Bambeike, C. van (1904). Sur l'évolution nucléaire et la sporulation chez Hydnangium carneum Wallr. Mém. Acad. R. Sci. Belgique, 54, p. 1-44.

Coker, W. C. \& Couch, J. N. (1928). The Gasteromycetes of the Eastern United States and Canada, p. 47-52.

Cunningham, G. H. (1935). The Gasteromycetes of Australasia. 17 : Some new species of Hymenogastraceae. Proc. Soc. N. S. Wales, 60, p. 119-120.

Dodge, C. W. (1931). Alpova, a new genus of Rhizopogonaceae, with further notes on Leucogaster and Arcangeliella. Ann. Mo. Bot. Gard., 18, p. 457-464.

Fischer, E. (1933). In Engler, A. \& Pranti, K. Pflanzenfam., 7a, p. 2-32.

Fitzpatrick, H. M. (1913). A comparative study of the fruitbody in Phallogaster, Hysterangium and Gautieria. Ann. Mycol. 11, p. 119-149.

GÄUmann, E. (1928). Comparative morphology of Fungi, translated and revised by DODGE, C. W. p. 485-519.

Lloyd, C. G. (1922). The Octaviania group. Mycological Writings 8, p. 1139-1142.

LoHwag, H. (1924). Zur Stellung und Systematik der Gastromyceten. Verhandl. Zool.Bot. Gesell. Wien 74, p. 38-55.

(1925). Zur Entwicklungsgeschichte und Morphologie der Gastromyceten. Beih. Bot. Centralb. 42, 2 Abt. p. 177-334.

Rehsteiner, H. (1892). Beiträge zur Entwicklungsgeschichte der Fruchtkörper einiger Gastromyceten. Bot. Zeit. 50, p. 761-771; 778-792; 865-878.

SWARTZ, D. (1933). Some developmental characters of species of Lycoperdaceae. Amer. Journ. Bot. 20, p. 440-465.

- (1935). The development of Calvatia craniiformis. Mycologia 27, p. 349-448. (1936). The development of Lycoperdon Acuminatum. Ibid. 28, p. 278-283.

Swartz, D. (1936). The development of Lycoperdon pedicellatum. Amer. Journ. Bot. 23, p. $4-7$.

Tulasne, L. \& C. (1851). Fungi hypogaei, p. 77.

Zelier, S. M. \& Dodge, C. W. (1919). Arcangeliella, Gymnomyces and Macowanites in North America. Ann. Mo. Bot. Gard. 6, p. 49-59.

(1935). New species of Hydnangiaceae. Ibid. 12, p. 365-373.

Zobel, J. B. (1842). In CoRda, A. J. C. Icones fungorum hucusque cognitorum. 6, p. 36.

\section{Explanation of Plate VI.}

Fig. A, Median section of very young fruitbody, showing homogeneous tissue. $\times 16$

Fig. B. Somewhat differentiated stage. $\times 15$. 
Fig. C. More advanced stage. $t$, tramal plate. $\times 11$.

Fig. D. Upper part of Fig. B, showing primary peridium $(p)$, hymenial fundament $(h)$, arch $(a)$, fold $(f)$, and inner tissue $(i) . \times 95$.

Fig. E. Part of a tissue of a very young fruitbody shown in Fig. A. $\times 450$.

Fig. F. Mature fruitbody. $\times 3 / 5$.

Fig. G. Median section of mature gleba and peridium. $\times 20$.

Fig. A-E made with fixed and stained materials.

Fig. ( $x$ made with fresh material.

\section{Über die Hemmung der Katalase-Wirkung durch Polyphenole und aromatische Polyamine.*}

Von

\section{Eijiro Yak̂kushiji.}

Mit 3 Textfiguren.

Eingegangen am 99. März 1937.

Die Hemmungserscheinung der Katalase-Wirkung durch Hydrochinon und Resorcin wurde von G. Schwab, B. Rosenfeld und L. Rudolph ${ }^{1)}$ untersucht. Sie haben darüber Frage aufgeworfen, dass es nicht eindeutig als Unterbrechung der Kettenreaktion im Sinne von F. HABER und $R$. WillstäTteR ${ }^{2)}$ betrachtet werden kann. Es braucht um diese Frage zu entscheiden, in bezug auf Fixierungsaffinität noch eingehender untersucht zu werden, da das Protohämin, das als prosthetische Gruppe der Katalase bekannt ist ${ }^{3)}$, Affinität zu Phenolverbindungen besitzen muss, weil einerseits nach der Untersuchung von T. Moni u. A. ${ }^{4}$ verschiedene Polyphenole und aromatische Polyamine von Pyridinhämin oxydiert werden und anderseits es von mir gezeigt wurde, dass Pilzlacease, die zahlreiche Polyphenole und aromatische Polyamine zu oxydieren vermag, wahrscheinlich als Parahämatin betrachtet werden kamn"). Angesichts dieser Tatsachen habe ich die Hemmung der Katalase-Wirkung durch verschiedene Polyphenole und

* Mitteilung aus dem botanischen Institut der kaiserlichen Universität zu Tokyo.

1) Schwab, G., B. Rosenferd u. T. Rudolph: Ber. Dtsch. ehem. Ges., 66 (1933), 661.

2) Навек, F. u. R. Willstätтек: Ber. Dtsch. chem. Ges., 64 (1931), 2844.

3) Zeile, K. u. H. Heliström: Ztschr. f. physiol. Chem., 192 (1930), 171. STERN, G.: J. biol. Chem., 114 (1936), 485.

4) Mori, T., K. Okunuki u. E. YakushiJi: Acta Phytochim., 10 (1937), im Druck.

5) YakushiJi, E.: Acta Phytochim., 10 (1937), im Druck. 
植物學䆶誌第五十一管第六圖版

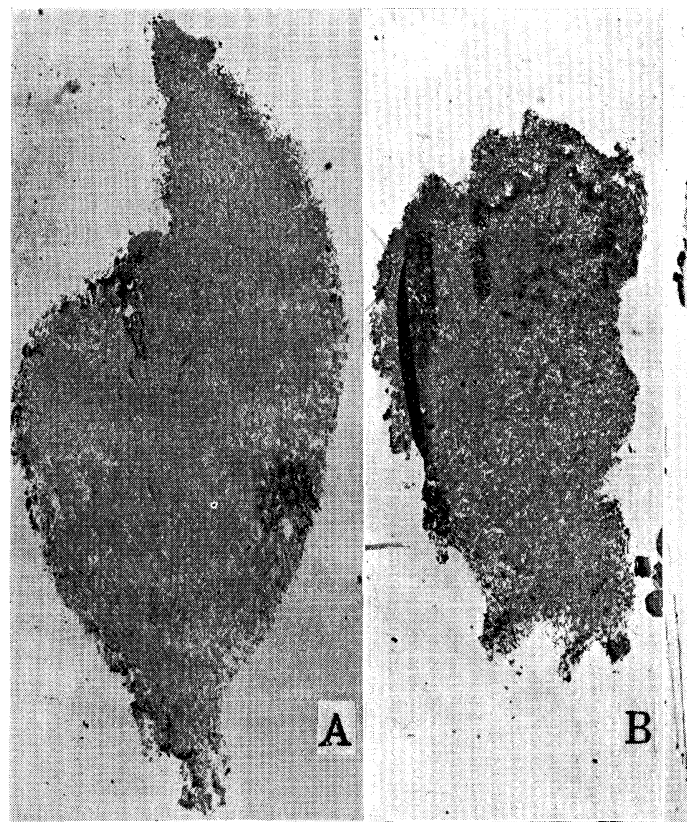

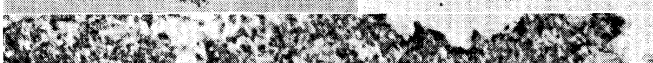

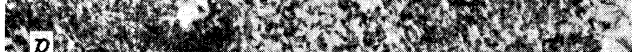

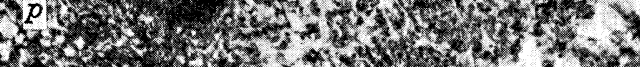

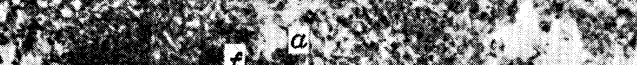

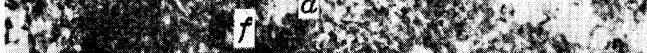
Bot. Mag. Tokyo, Vol. LI, Pl. VI.

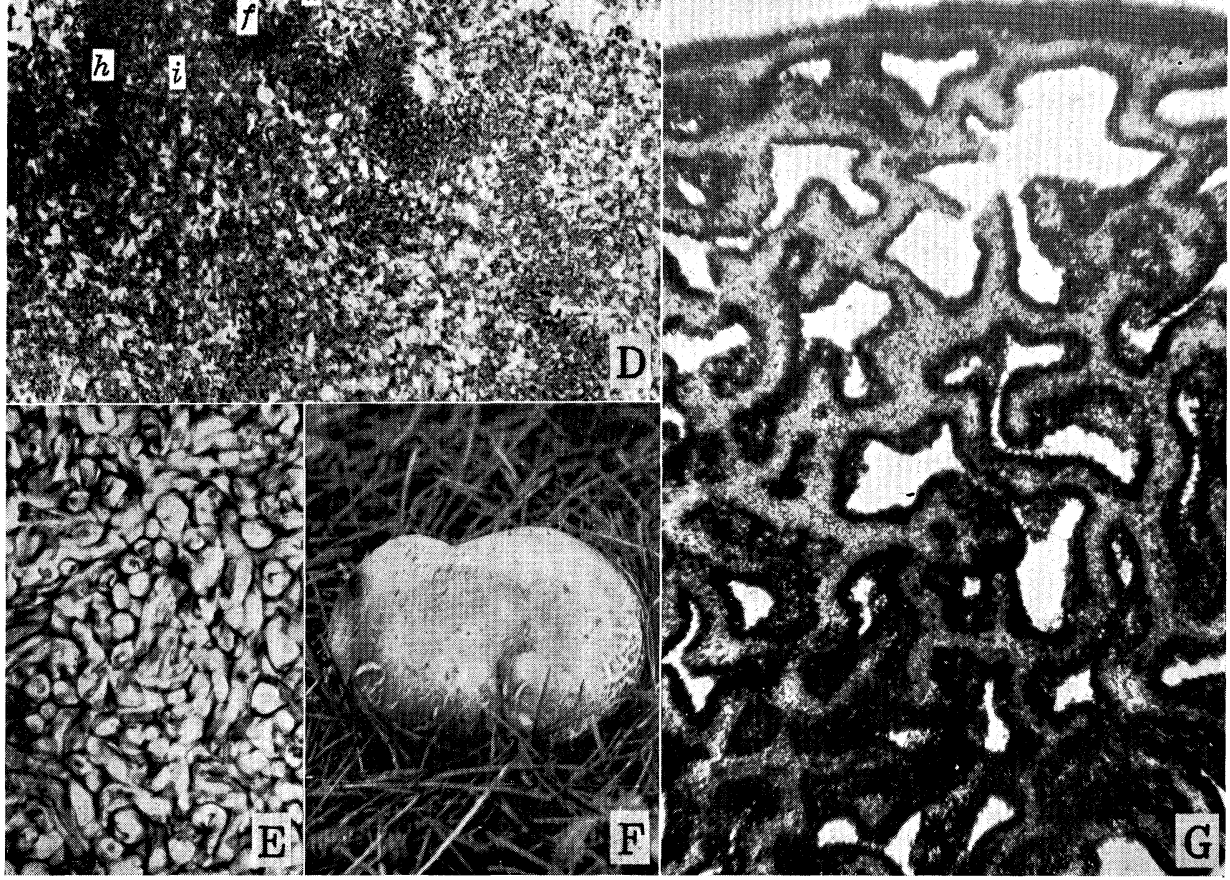

Y. KobaYasi-New species of Octariania. 